\title{
Use of Meat-Bone Paste to Develop Calcium-Enriched Liver Pâté
}

\author{
Zhanibek Yessimbekov ${ }^{1, *}$, Aitbek Kakimov ${ }^{1}$, Nicola Caporaso ${ }^{2,3}$, Anuarbek Suychinov ${ }^{4}$, Baktybala Kabdylzhar ${ }^{1}$, \\ Mohammad Ali Shariati ${ }^{5}$ (D), Assemgul Baikadamova ${ }^{1}$, Rubén Domínguez ${ }^{6} \mathbb{D}^{\mathbb{D}}$ and José M. Lorenzo ${ }^{6,7}, * \mathbb{D}$
}

1 Department of Technological Equipment and Mechanical Engineering, Shakarim State University of Semey, Semey 071412, Kazakhstan; bibi.53@mail.ru (A.K.); baktybala.20@mail.ru (B.K.); asemgul93@yandex.ru (A.B.)

2 Department of Food Sciences, School of Biosciences, The University of Nottingham, Nottingham LE12 5RD, UK; nicola.caporaso3@unina.it

3 Department of Agricultural and Food Sciences, University of Naples "Federico II", 80055 Naples, Italy

4 Kazakh Research Institute of Processing and Food Industry (Semey Branch), Semey 071410, Kazakhstan; asuychinov@gmail.com

5 Department of Technology of Food Production, K.G. Razumovsky Moscow State University of Technologies and Management (The First Cossack University), 109004 Moscow, Russia; shariatymohammadali@gmail.com

6 Centro Tecnológico de la Carne de Galicia, Avda. Galicia n 4, Parque Tecnológico de Galicia, San Cibrao das Viñas, 32900 Ourense, Spain; rubendominguez@ceteca.net

7 Área de Tecnología de los Alimentos, Facultad de Ciencias de Ourense, Universidad de Vigo, 32004 Ourense, Spain

* Correspondence: zyessimbekov@semgu.kz (Z.Y.); jmlorenzo@ceteca.net (J.M.L.); Tel.: +777-520-525-255 (Z.Y.)

Citation: Yessimbekov, Z.; Kakimov, A.; Caporaso, N.; Suychinov, A.; Kabdylzhar, B.; Shariati, M.A.; Baikadamova, A.; Domínguez, R.; Lorenzo, J.M. Use of Meat-Bone Paste to Develop Calcium-Enriched Liver Pâté. Foods 2021, 10, 2042. https:// doi.org/10.3390/foods10092042

Academic Editor: Rosario Ramirez

Received: 29 July 2021

Accepted: 26 August 2021

Published: 30 August 2021

Publisher's Note: MDPI stays neutral with regard to jurisdictional claims in published maps and institutional affiliations.

Copyright: (c) 2021 by the authors. Licensee MDPI, Basel, Switzerland. This article is an open access article distributed under the terms and conditions of the Creative Commons Attribution (CC BY) license (https:/ / creativecommons.org/licenses/by/ $4.0 /)$.
Abstract: The production technology of meat-bone paste and its effect on chemical, mineral and amino acid compositions of liver pâte were studied. The liver was replaced by meat-bone paste in the concentration of 5, 10,15,20, and $25 \%$ for the production of experimental samples. The compositional analysis of pâté manufactured with meat-bone paste showed that the reformulation did not influence the content of moisture $(\sim 56 \%)$, fat $(\sim 28 \%)$, or protein $(\sim 11 \%)$ while producing a significant increase of ash and a decrease of carbohydrates in comparison with control pâtés. The higher amounts of minerals of bone-meat paste, including calcium $(3080 \mathrm{mg} / 100 \mathrm{~g})$, magnesium $(2120 \mathrm{mg} / 100 \mathrm{~g})$, phosphorous $(2564 \mathrm{mg} / 100 \mathrm{~g})$, and iron $(7.30 \mathrm{mg} / 100 \mathrm{~g})$, explained the higher amount of both ash and these minerals in the reformulated samples compared to the control samples. The total caloric value $(\sim 300 \mathrm{kcal} / 100 \mathrm{~g})$ was also unaffected by the addition of bone-meat paste. The content of both essential and non-essential amino acids decreased with the inclusion of meat-bone paste, although this decrease was lower in essential $(6280 \mathrm{mg} / 100 \mathrm{~g}$ in control vs. $5756 \mathrm{mg} / 100 \mathrm{~g}$ in samples with $25 \%$ of meat-bone paste) than in non-essential amino acids $(6080 \mathrm{mg} / 100 \mathrm{~g}$ in control vs. $3590 \mathrm{mg} / 100 \mathrm{~g}$ in samples with $25 \%$ of meat-bone paste). This fact is due to several essential amino acids not showing differences between control and reformulated samples, while in non-essential amino acids, these differences were greater. The results of this study showed that meat-bone paste addition is a good strategy to produce liver paté enriched in minerals and with minimum influence on the content of the other important nutrients. Therefore, these results can be used for the design of new liver pâté with an increased nutritional significance by using meat industry by-products. According to the balance of minerals, the use of $15 \%$ of meat-bone paste to reformulate liver pâté is the best strategy used in the present research. However, additional studies on the stability (during storage), shelf-life, and sensory acceptability of these reformulated pâtés should be carried out.

Keywords: healthy meat products; mineral enrichment; calcium; functional meat products; meat by-products

\section{Introduction}

The composition of liver pâté can have a substantial impact on its nutritional characteristics, with a wide variety of liver pâté recipes reported in the literature and sold on the 
market worldwide. Such recipes can include beef liver, beef brain, and other beef components [1]; pork fat and other pig-derived products [2-4]; poultry fats and poultry-derived products [5]; and others [6]. Each of these components has unique chemical properties, flavors, and associated risks. In general, flavors derived from pork and beef are known to be more intense compared to poultry-derived analogues [7]. The food industry that manufactures liver pâté must consider all of these factors in designing a recipe, with the goal of obtaining a liver pâté that is safe, stable, rich in flavor, and appealing to consumers [8,9].

Of the aforementioned wide variety of ingredients that can be potentially used in liver pâté, meat-bone paste is of great interest [10]. Meat-bone paste has been shown to be rich in calcium and phosphorus [11] and as a result, has been studied as a possible dietary supplement to combat the ageing process [12]. The processing of meat-bones into such paste can affect its texture and the properties of the food to which is added, but amounts above $15 \%$ are known to have deleterious effects [13].

Among animal by-products, bones have almost no use in meat technology. This is because according to current legislation, bones are considered not suitable for human consumption and are treated as animal by-products [14]. Most small and medium meat companies dispose of them, whereas big companies produce bone adhesive, gelatin, bone flour, etc. However, bone is a rich source of mineral elements (calcium, phosphorous, magnesium, iron, etc.), protein (collagen type), and fat [15]. Therefore, although the characteristics of this product present promising advantages and opportunities for the reformulation of meat products, in addition to in-depth studies on its use, a change in legislation is also needed to include meat-bone paste as an ingredient for human consumption. This will undoubtedly require specific handling of the bones at the slaughterhouse level to ensure their safety. The improvement of bone processing technology and the creation of a new type of equipment allow using the bones of slaughtered animals for food purposes without losing nutrients. Mainly, in large meat companies, bone is used for the production of meat and bone meal for animal feeding. Meat and bone meal is a source of proteins as it contains essential amino acids which are vital for animal growth. Among the essential amino acids, the meat and bone meal contains large amounts of lysine, valine, isoleucine, and leucine [16].

Meat and meat products are widely consumed, and among them, pâtés are highly appreciated by consumers [6,17]. However, although meat contains high amounts of important nutrients (proteins, iron, vitamins, etc.), traditional meat products, such as pâté, do not provide the human body with a sufficient number of mineral elements, especially in relation to calcium. This is due to meat being characterized by typical low calcium contents (10-12 mg/100 g) and an unbalanced calcium to phosphorous ratio (1:15-20), as opposed to the recommended 1:1 ratio, leading to malassimilation of these elements [18]. With this in mind, the reformulation of pâtés using meat-bone paste as a raw material could allow the mineral supplementation and produce an enriched meat product. Some studies and patents were proposed for the isolation and hydrolysis of proteins from meat-bone paste $[19,20]$. However, these methods of bone processing are based on heating and acid treatment, which leads to some nutrient loss. To overcome these limitations, particular emphasis should be placed on the ultrafine grinding process of bones for food purposes. Ultrafine grinding of bone allows producing meat-bone paste that can be used in the formulation of sausage, pâtés, ham, meat semi-products, etc. Additionally, this meat-bone paste enriches meat products with essential mineral and protein substances. Ultrafine bone grinding processes begin by crushing the bone to $1-3 \mathrm{~mm}$ particles, followed by ultrafine grinding to yield 50-100 $\mu \mathrm{m}$ particles. This processing can be used to make paste-like products, such as pâté, that have a soft texture and are fully digestible by humans. Moreover, since the meat-bone grinding process does not involve thermal treatments, the vitamin and mineral content is preserved. The use of grinding and ultrafine grinding technology for obtaining meat-bone pastes was previously reported by several authors and companies [21-23]. Additionally, the use of meat-bone paste for the development of functional meat products was also studied [24,25]. 
Thus, the aim of the current study was to apply technology for manufacturing liver pâté made with meat-bone paste in order to investigate its impact on the chemical composition of the final product. The liver pâté was made with a meat-bone paste at different levels (from 5 to $25 \%$ of the total ingredients), and other ingredients included beef liver, beef brain, pork back fat, sautéed onion, salt, white sugar, and other spices. A detailed analysis of the chemical composition, minerals, and amino acid content of the liver pâté was carried out.

\section{Materials and Methods}

\subsection{Meat-Bone Paste Preparation}

A patent was granted by the Republic of Kazakhstan \#2202 on 15 June 2017 for the method developed by Kakimov et al. [15]. Bone grinding processing by this procedure allows obtaining a meat-bone paste which is free of hard bone particles; thus, it results in a product that is smooth and soft to the tongue of the consumer.

Beef tissue and bones (rib and vertebrae) were donated by the Tyumenbayev Meat Company in Semey city, Republic of Kazakhstan. Meat and rib bones from cattle were obtained after carcass boning and were packed in clean polyethylene bags that were rapidly transported to the laboratory and stored at $-18^{\circ} \mathrm{C}$ for $2 \mathrm{~h}$. The total weight of bone and meat was $50 \mathrm{~kg}$ (25 kg each).

Bones with meat tissue were washed with cold water and then crushed into 50-70 mm long fragments. Cutting bones into small pieces was done manually with an axe. The bone fragments were stored at $-18{ }^{\circ} \mathrm{C}$ to $-20^{\circ} \mathrm{C}$ before loading into the hopper of a crushing machine equipped with an $8 \mathrm{~mm}$ diameter meat grinder plate. The bone was ground and crushed again using a $3 \mathrm{~mm}$ meat grinder plate; water was then added to a 1:1 ratio $(w / w)$. The mixture was frozen at $-3{ }^{\circ} \mathrm{C}$ to $-5{ }^{\circ} \mathrm{C}$ for $1 \mathrm{~h}$ and then ground using a micro-milling machine having rotational knives spaced at $0.50 \mathrm{~mm}$. The resulting meat-bone paste (MBP) was used to prepare pâté meat batters.

\subsection{Liver Pâté Preparation}

As a control, we used meat pâté with a formulation approved and reported in National Standard GOST 12319-77 [26]. In other samples, the beef liver was replaced by meat-bone paste in amounts ranging from 5 to $25 \%$ (Table 1 ). The manufacturing steps and conditions are summarized in Figure 1. All ingredients were inspected for safety in accordance with existing specifications and standards. Then, beef liver was carefully trimmed, removing the membrane, bile ducts, and other inclusions. After trimming, the beef liver was soaked in running water for $2 \mathrm{~h}$ for removing blood clots. At that point, the liver was cut into pieces and blanched in hot water (water/liver ratio 3:1) for $25 \mathrm{~min}$. After blanching, the liver was rinsed in cold water and chopped in a meat grinder with 2-3 mm hole diameter of plate. Beef brains were used for pâté elaboration after veterinary and sanitary inspection, in accordance with regulations [27]. Beef brains were blanched for 10-15 min and cooled to $12{ }^{\circ} \mathrm{C}$. After cooling, the beef brains were chopped on the meat grinder with $2-3 \mathrm{~mm}$ hole diameter of plate. Then, beef liver, beef brains, meat-bone paste, pork fat, and spices were weighed according to the recipe (Table 1). The ingredients of the pâté were mixed in a cutter L5-FKM (Russia) for 5-7 min. 
Table 1. Formulations of liver pâté with different amount of meat-bone paste (\%).

\begin{tabular}{ccccccc}
\hline \multirow{2}{*}{ Ingredients } & \multicolumn{7}{c}{ Samples } \\
\cline { 2 - 7 } & Control & MBP-5 & MBP-10 & MBP-15 & MBP-20 & MBP-25 \\
\hline Meat-bone paste & 0.00 & 5.00 & 10.0 & 15.0 & 20.0 & 25.0 \\
Beef liver & 55.0 & 50.0 & 45.0 & 40.0 & 35.0 & 30.0 \\
Beef brain & 10.0 & 10.0 & 10.0 & 10.0 & 10.0 & 10.0 \\
Pork back-fat & 30.0 & 30.0 & 30.0 & 30.0 & 30.0 & 30.0 \\
Sauteed onion & 3.10 & 3.10 & 3.10 & 3.10 & 3.10 & 3.10 \\
Salt & 1.30 & 1.30 & 1.30 & 1.30 & 1.30 & 1.30 \\
White sugar & 0.40 & 0.40 & 0.40 & 0.40 & 0.40 & 0.40 \\
Spices * & 0.20 & 0.20 & 0.20 & 0.20 & 0.20 & 0.20 \\
Total & 100 & 100 & 100 & 100 & 100 & 100 \\
\hline
\end{tabular}

* Black pepper and allspice; nutmeg; cinnamon; cloves (in equal quantity).

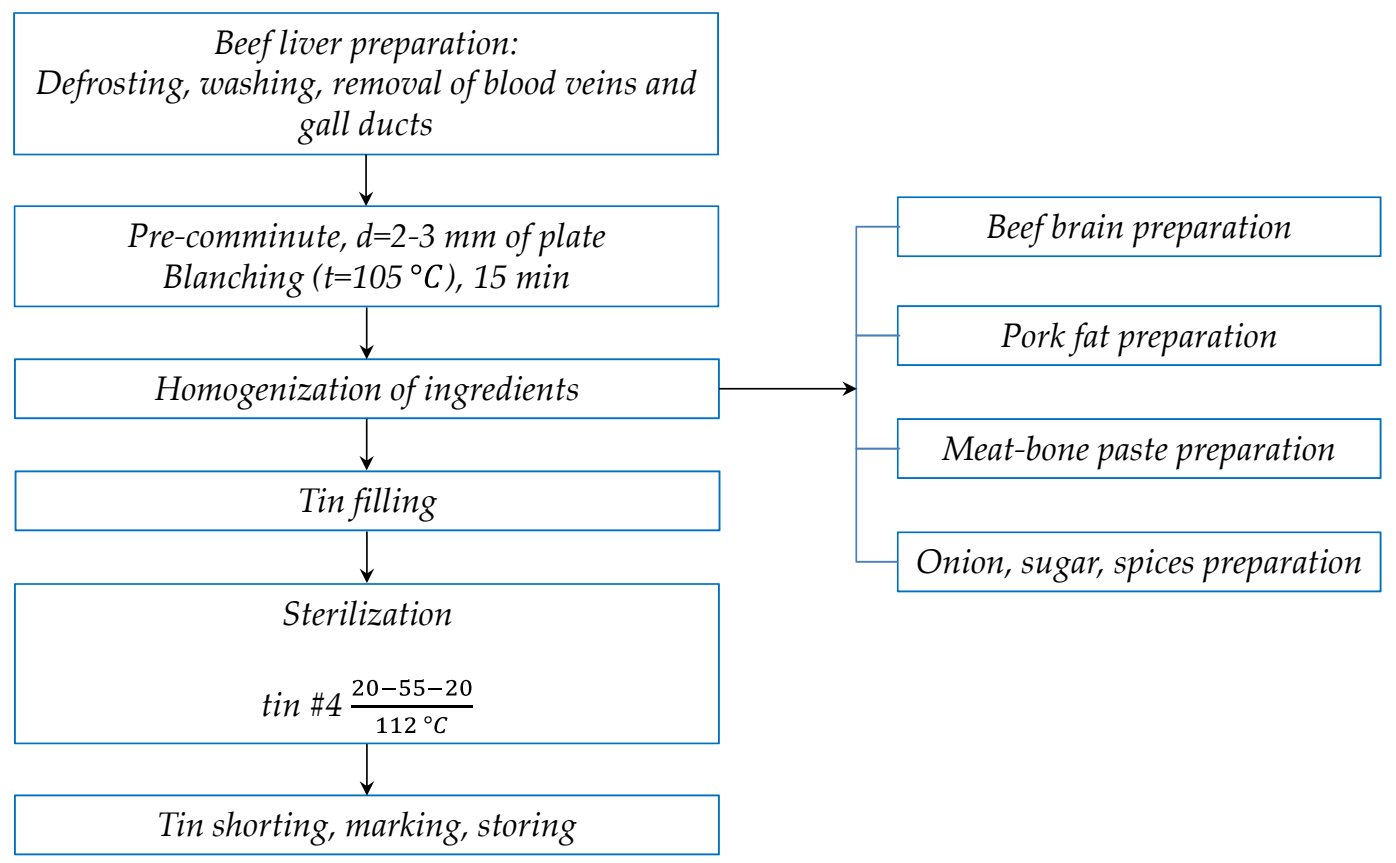

Figure 1. Flow sheet of liver pâté preparation.

The pâté mass was filled by dosing machines into metal cans (height $70.0 \mathrm{~mm}$; diameter $72.8 \mathrm{~mm}$; volume $260 \mathrm{~mL}$ ) and sealed hermetically on the capping machine IPKS-127UZ (Moscow, Russia). The net weight of cans was $250 \mathrm{~g}$. Capped cans after washing were loaded into autoclave baskets and sent for sterilization in autoclave IPKS-128-500 (Moscow, Russia). The time from closing the cans to the beginning of sterilization should not exceed $30 \mathrm{~min}$. Sterilization was carried out using the following program: initial 20 min to reach the treatment temperature in the autoclave $\left(112{ }^{\circ} \mathrm{C}\right.$; heating step), then maintaining cans for $65 \mathrm{~min}$ at $112{ }^{\circ} \mathrm{C}$ and $0.08 \mathrm{MPa}$ (treatment conditions), and finally another $20 \mathrm{~min}$ to lower the temperature (cooling step).

All manufacturing processes were replicated twice (with the same ingredients and processing conditions), and five cans of each batch and replicate were analyzed for the chemical, mineral, and amino acid composition.

\subsection{Determination of Chemical Composition}

The determination of the chemical composition (moisture, fat, ash, and protein) was based on the methods previously described [23]. Briefly, to determine moisture, the samples were dried in a drying oven, and moisture was calculated according to the standards $[28,29]$. After moisture determination, each dried sample was used for fat determination according 
to the standard GOST 23042-86 [30]. To measure the ash content, the samples were calcined in a muffle furnace $\left(500^{\circ} \mathrm{C}-600^{\circ} \mathrm{C}\right)$. Finally, the protein content was analyzed according to the standard GOST 25011-81 [31].

The method used for carbohydrate determination is based on extraction of sugars from the analyzed sample with distilled water followed by HPLC analysis to identify the composition and determine the carbohydrate mass fraction. Briefly, $10 \mathrm{~g}$ of pâté samples was mixed with $100 \mathrm{~mL}$ of distilled water, and the obtained mixture was mixed with a magnetic stirrer at room temperature for $1 \mathrm{~h}$. The obtained extract was filtered through a paper filter and then through a $0.45 \mu \mathrm{m}$ membrane filter. The prepared extract was then analyzed by HPLC.

The carbohydrates were quantified using an HPLC (Shimadzu LC-20 Prominence liquid chromatography system; Shimadzu, Kyoto, Japan) equipped with a refractive index detector (RID). For carbohydrate determination, $20 \mu \mathrm{L}$ of each sample was injected, and carbohydrates were separated using column with aminopropyl stationary phase for carbohydrate separation (Zorbax Carbohydrate $250 \times 4.6 \mathrm{~mm}, 5 \mu \mathrm{m}$, Agilent, Santa Clara, CA, USA), using acetonitrile:water in proportion $82 \%: 18 \%(v / v)$ as eluent at $0.5 \mathrm{~mL} / \mathrm{min}$ in isocratic mode. The identification of carbohydrates was carried out by comparison individual peaks with the retention times of pure standards. The total analysis time was $20 \mathrm{~min}$. The concentration of each carbohydrate was calculated with an external calibration, and the results of total carbohydrate content was expressed as g/100 g of pâté.

\subsection{Caloric Value Calculation}

Caloric value was calculated according to Equation (1):

$$
C V=4(P+C)+9 F
$$

where $\mathrm{CV}$ - caloric value, $\mathrm{kCal} ; \mathrm{P}$-protein content, $\mathrm{g} ; \mathrm{F}$-fat content, $\mathrm{g} ; \mathrm{C}$ - carbohydrate content, g; 4-caloric index for protein and carbohydrate; and 9-caloric index for fat.

\subsection{Mineral Composition Determination}

One to two grams of the sample was placed in a high-pressure Teflon container. Each sample was combusted at $400{ }^{\circ} \mathrm{C}$ for $4 \mathrm{~h}$ and then to $600^{\circ} \mathrm{C}$ for $2 \mathrm{~h}$ using a muffle furnace. A representative $1 \mathrm{~g}$ (dry weight) of ashes was digested by adding $3 \mathrm{~mL} \mathrm{HNO}_{3}$ and $2 \mathrm{~mL}$ of HF. This was placed in a microwave at $200{ }^{\circ} \mathrm{C}$ for $20 \mathrm{~min}$ (Berghof Speed Wave microwave system, Bremen, Germany). After microwave digestion, the samples were diluted with 1\% $\mathrm{HNO}_{3}$ in a $10 \mathrm{~mL}$ vessel.

The content of elements in muscle samples was determined with an inductively coupled plasma mass spectrometric method (ICP-MS, Varian-820 MS, Varian Company, Canberra, Australia). The method was validated with certified reference materials. Calibration standards Var-TS-MS, IV-ICPMS-71A (Inorganic Ventures Company, Christiansburg, VA, USA) were used for calibrating the mass spectrometer. The sensitivity of the mass spectrometer was tuned using a diluted calibration solution Var-TS-MS with a concentration of $\mathrm{Ba}, \mathrm{Be}, \mathrm{Ce}, \mathrm{Co}, \mathrm{B}, \mathrm{Pb}, \mathrm{Mg}, \mathrm{Tl}$, and $\mathrm{Th}$ of $10 \mu \mathrm{g} / \mathrm{L}$. Three calibration solutions were used for the detector calibration. They were IV-ICPMS-71A of $\mathrm{Cd}, \mathrm{Pb}, \mathrm{Cu}$, and $\mathrm{Zn}$ elements diluted to 10,50 , and $100 \mu \mathrm{g} / \mathrm{L}$. Discrepancies between the certified values and concentrations quantified were below $10 \%$. The operating parameters of the inductively coupled plasma mass spectrometer Varian ICP 820-MS were as follows: plasma flow $17.5 \mathrm{~L} / \mathrm{min}$; auxiliary flow $1.7 \mathrm{~L} / \mathrm{min}$; sheath gas $0.2 \mathrm{~L} / \mathrm{min}$; nebulizer flow $1.0 \mathrm{~L} / \mathrm{min}$; sampling depth $6.5 \mathrm{~mm}$; RF power $1.4 \mathrm{~kW}$; pump rate $5.0 \mathrm{rpm}$; and stabilization delay $10.0 \mathrm{~s}$. All analyses were performed in triplicates, and the results were expressed as $\mathrm{mg} / 100 \mathrm{~g}$ sample.

\subsection{Amino Acid Composition Determination}

Determination of the amino acid composition of meat samples was performed based on the phenylisothiocyanate (PITC) procedure described by Rudenko and Kartsova [32]. For determination of amino acid composition in meat samples, $100 \mathrm{mg}$ of homogenized 
sample was mixed with $10 \mathrm{~mL}$ of $6 \mathrm{M}$ hydrochloric acid in vials under nitrogen atmosphere. Then, vials were closed and turned to the thermostat with temperature $110{ }^{\circ} \mathrm{C}$ for at least $17 \mathrm{~h}$. Then, hydrolyzed solutions were cooled to room temperature and filtered. Measurements of $0.5 \mathrm{~mL}$ of the filtered solutions were dried in the airflow at $65{ }^{\circ} \mathrm{C}$. To the dried aliquots, $100 \mu \mathrm{L}$ of $0.15 \mathrm{M}$ solution of sodium hydroxide was added and stirred for $10 \mathrm{~min}$. After this, $350 \mu \mathrm{L}$ of phenylisothyocyanate (PITC) solution in isopropyl alcohol and $50 \mu \mathrm{L}$ of water were added. Solutions were stirred and dried at $65^{\circ} \mathrm{C}$ in the airflow and water bath. Dry residues of solutions were dissolved in $1 \mathrm{~mL}$ of water and filtered through $0.45 \mu \mathrm{m}$ filters. For identification (by retention times) and quantification (based on external standard calibration), the commercial standards of the amino acids (Asp, Asn, Glu, Gln, o-Pro, Ser, Gli, Gis, Arg, Tre, Ala, Pro, Tir, Val, Lys, Ile, Ley, Phe, Met, Cys) were derivatized using PITC procedure as described below. The amino acid derivatives were analyzed using a Shimadzu Prominence LC-20 liquid chromatograph equipped with $250 \times 4 \mathrm{~mm}$ Supelco C18 $(5 \mu \mathrm{m})$ column and UV detector at wavelength $254 \mathrm{~nm}$ [32]. Gradient mode (Table 2) at $1.2 \mathrm{~mL} / \mathrm{min}$ eluent flow and $40{ }^{\circ} \mathrm{C}$ of column temperature was used. As mobile phase, $6 \mathrm{mM}$ solution of sodium acetate with $\mathrm{pH} 5.5$ (eluent A), 1\% (v/v) solution of isopropyl alcohol in acetonitrile (eluent $\mathrm{B}$ ), and $6 \mathrm{mM}$ solution of sodium acetate with $\mathrm{pH} 4.05$ (eluent C) were used.

Table 2. Gradient mode parameters of HPLC determination of amino acids.

\begin{tabular}{cccc}
\hline Time (min) & & Volume of Eluent (\%) & \\
\hline & Eluent A & Eluent B & Eluent C \\
\hline 101 & 96.0 & 4.00 & 0.00 \\
10.0 & 37.0 & 11.0 & 52.0 \\
13.0 & 88.5 & 11.5 & 0.00 \\
21.0 & 80.0 & 20.0 & 0.00 \\
22.0 & 58.0 & 22.0 & 20.0 \\
24.0 & 0.00 & 24.0 & 76.0 \\
32.0 & 0.00 & 33.5 & 66.5 \\
32.01 & 20.0 & 80.0 & 0.00 \\
35.3 & 20.0 & 80.0 & 0.00 \\
41.31 & 97.0 & 3.00 & 0.00 \\
\end{tabular}

\subsection{Microstructure Analysis}

Microstructure of meat-bone paste was observed by low vacuum scanning electron microscope JSM-6390LV JEOL (Tokyo, Japan), following the procedure described by Rao et al. [33].

\subsection{Statistical Analysis}

Statistical analysis was performed using Statistica 12.0 (STATISTICA, 2014; StatSoft Inc., Tulsa, OK, USA). After checking normal distribution and variance homogeneity (Shapiro-Wilk), the differences between liver pâté samples were evaluated using oneway ANOVA. The Tukey HSD test was used for means comparisons. Differences were considered to be statistically significant at $p \leq 0.05$. Data are presented as mean values \pm standard deviation (SD).

\section{Results and Discussion}

\subsection{Mineral Composition of Meat-Bone Paste}

In order to determine the chemical characteristics of the meat-bone paste used for the reformulation of liver pâté, an initial characterization of it was carried out. The chemical composition of meat-bone paste was characterized by high ash content $(11.4 \%)$, while the protein, fat, and moisture contents were $13.6 \%, 5.22 \%$, and $69.7 \%$, respectively (Table 3 ). The calculated caloric value of the meat-bone paste was $102 \mathrm{kcal}$. In another study, the 
authors also found high amounts of ashes in meat-bone paste [34]. However, these authors reported higher amounts of ash (29\%), protein $(24 \%)$, and fat $(12 \%)$ and lower values of moisture (34\%) than those observed in our study, which could be related to differences in the initial material used for the production of meat-bone paste.

Table 3. Chemical (g/100 g) and mineral composition (mg/100 g) of meat-bone paste.

\begin{tabular}{cc}
\hline \multicolumn{2}{c}{ Chemical Composition } \\
\hline Moisture & $69.7 \pm 1.57$ \\
Protein & $13.6 \pm 0.32$ \\
Fat & $5.22 \pm 0.14$ \\
Ash & $11.4 \pm 0.36$ \\
Caloric value (Kcal/100 g) & 102 \\
& \\
Calcium & Minerals \\
Potassium & $3080 \pm 72.7$ \\
Magnesium & $115 \pm 1.86$ \\
Sodium & $2120 \pm 43.5$ \\
Phosphorous & $390 \pm 14.8$ \\
Copper & $2564 \pm 50.4$ \\
Iron & $1.33 \pm 0.04$ \\
Manganese & $7.30 \pm 0.14$ \\
Zinc & $0.10 \pm 0.002$ \\
\end{tabular}

Bones are tough and hard tissue as a result of the combination of mineral elements with organic structure. Bone tissue is a rich source of mineral salts. It contains $98 \%$ of all inorganic salts presented in the human body, and among them, $99 \%$ of calcium, $87 \%$ of phosphorous, $58 \%$ of magnesium, and $46 \%$ of sodium [16]. Therefore, as expected, the mineral composition of meat-bone paste used in this study was dominated by calcium (3080 mg/100 g), phosphorous (2564 mg/100 g), magnesium (2120 mg/100 g), sodium $(390 \mathrm{mg} / 100 \mathrm{~g})$, potassium $(115 \mathrm{mg} / 100 \mathrm{~g})$, and iron $(7.30 \mathrm{mg} / 100 \mathrm{~g})$. Trace elements of copper $(1.33 \mathrm{mg} / 100 \mathrm{~g})$, manganese $(0.10 \mathrm{mg} / 100 \mathrm{~g})$, and zinc $(2.15 \mathrm{mg} / 100 \mathrm{~g})$ were also identified (Table 3). Thus, the analysis of meat-bone paste demonstrated high amounts of important minerals for human nutrition. The mineral composition found in the meat-bone paste used in the present study agrees with that reported by other researchers in a protein compound batter made with meat-bone paste and other meat by-products [35]. In fact, in this study, the authors reported that the most important minerals in this protein compound are higher amounts of calcium, phosphorous, magnesium, sodium, and potassium. Similar to our findings, other researchers also reported high amounts of calcium $(57.7 \%)$, phosphorous $(25.4 \%)$, and sodium $(3.80 \%)$, while the content of magnesium $(1.86 \%)$ and potassium $(1.12 \%)$ was lower [36].

\subsection{Microstructure Analysis of Meat-Bone Paste}

As can be seen in the image of bone particles, magnified 50 times where the bone particle sizes were measured (Figure 2), particle sizes exceeding $0.40 \mathrm{~mm}$ (400 microns) were not detected. 


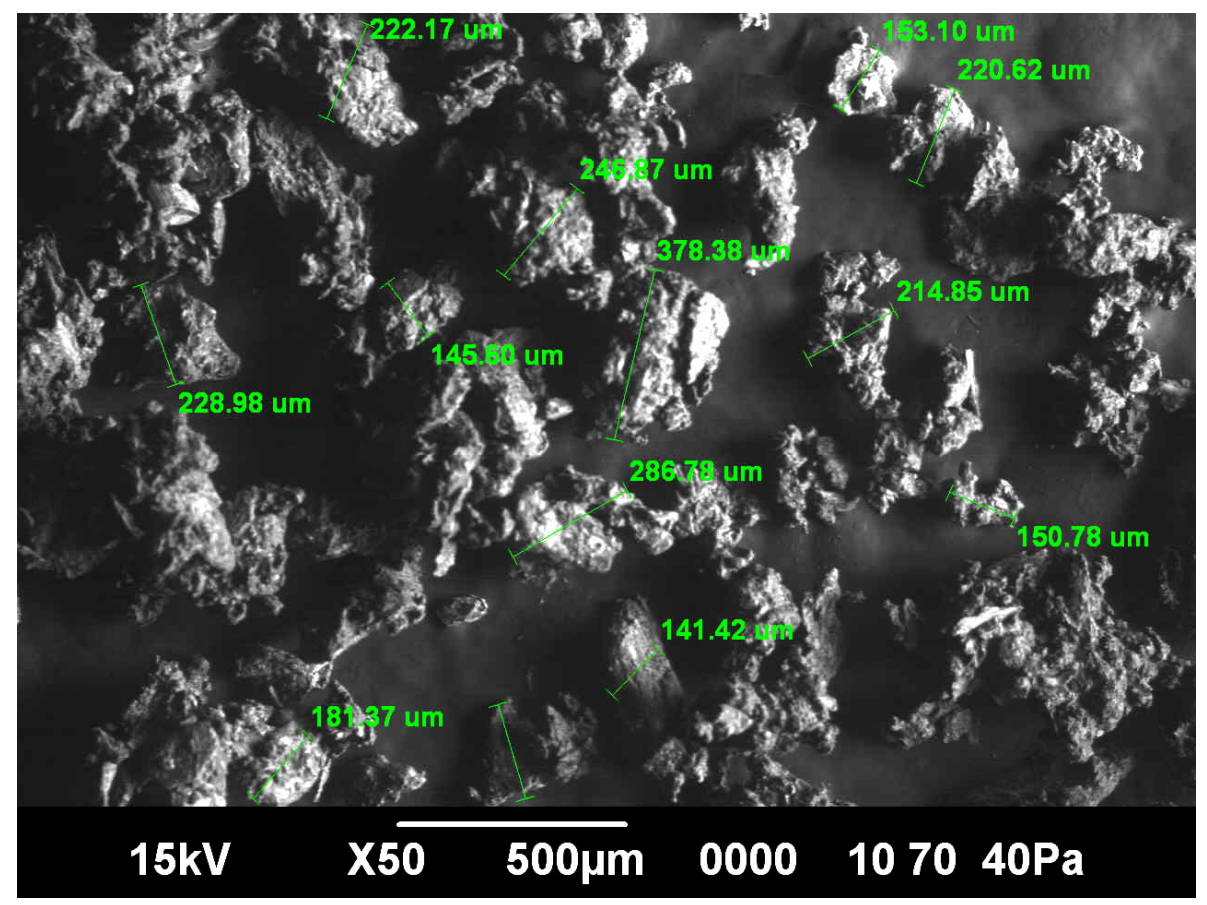

Figure 2. Bone particle sizes of meat-bone paste.

On the basis of the sieve analysis of the meat-bone paste after grinding on a colloid machine with a gap between the grinding wheels of $0.10 \mathrm{~mm}$, it was found that the mass fraction of bone particles ranging in size from $0.10 \mathrm{~mm}$ to $0.25 \mathrm{~mm}$ is more than $95 \%$. Bone particles that were beyond $0.25 \mathrm{~mm}$ were less than $5 \%$ and, as mentioned, particles of $0.40 \mathrm{~mm}$ (or higher) were not detected. Similar findings were obtained in a previous study, in which the meat-bone particle size after grinding on the colloid mincing machine was from 0.20 to $1.5 \mathrm{~mm}$, while after grinding on the superfine machine, the particle size was reduced to less than $0.10 \mathrm{~mm}$ [34]. A more recent study concluded that after grinding in the masscolloider with a gap of $0.25 \mathrm{~mm}$, the bone particle size ranged between $0.14 \mathrm{~mm}$ and $0.37 \mathrm{~mm}$, while after using a masscolloider with a gap of $0.10 \mathrm{~mm}$, the bone size decreased and ranged between $0.045 \mathrm{~mm}$ and $0.19 \mathrm{~mm}$ [13]. These results agree with our findings, and they demonstrate that the process and conditions for obtaining the meat-bone paste are good and that this allows obtaining a meat-bone paste with a smooth texture, which is not perceptible by consumers, and which is digestible by humans. Therefore, the meat-bone paste obtained in this research can be used for the production or reformulation of meat products: in our case, liver pâté.

\subsection{Liver Pâte Chemical and Mineral Composition}

The analysis of chemical composition showed similar values of moisture ( $56 \%)$, protein $(\sim 11 \%)$, and fat $(\sim 27 \%)$ compared to those reported by other authors concerning liver pâté $[3,6,17]$ and slightly different (lower protein and higher fat contents) in comparison with meat pâtés [4]. In the case of pâté, as in other meat products, the final composition of the product depends on the composition, type, and proportions of the ingredients used during processing. Therefore, the differences found between the studies could be attributed to the ingredient composition and the specific formulation used for pâte manufacturing in each study.

In the present study, the addition of meat-bone paste significantly affected the content of ash and carbohydrate, while it did not influence any other parameters (Table 4). Although the protein values were not significantly influenced $(p>0.05)$ by the reformulation, a slight and progressive decrease in its content could be observed as the meat-bone paste proportion increased. The lower amount of protein in meat-bone paste (13.6\%) in comparison with liver protein content (18.9\%) [37] could be the explanation for this behavior. Fat and moisture 
contents were constant in all pâté samples. The similar fat content between meat-bone paste and beef liver (5.22\% in meat-bone paste vs. 3.80\% in the beef liver [37]) could explain the lack of significant differences in this parameter when liver pâté is reformulated with meatbone paste. In contrast, the ash content increase from $0.92 \%$ (control) to $3.42 \%$ (BMP-25) could be explained by the high amount of minerals in the meat-bone paste. As discussed in the previous section, the meat-bone paste used in the present study presented high ash content $(11.4 \%)$ in comparison with $1.80 \%$ of ash found in beef liver [37], which exerted a clear influence on the evolution of these parameters when the pâté was reformulated. Finally, the carbohydrate content was also affected by the inclusion of meat-bone paste as a liver replacer. In this case, a progressive decrease of carbohydrates was observed as the proportion of meat-bone paste used in the pâté formulation increased.

Table 4. Chemical composition of liver pâtés with meat-bone paste.

\begin{tabular}{|c|c|c|c|c|c|c|c|}
\hline \multirow{2}{*}{ Parameter $^{1}$} & \multirow{2}{*}{ Control } & \multicolumn{5}{|c|}{ Pâté Reformulated with Meat-Bone Paste } & \multirow{2}{*}{$p$ Value } \\
\hline & & MBP-5 & MBP-10 & MBP-15 & MBP-20 & MBP-25 & \\
\hline Moisture & $56.9 \pm 1.27$ & $56.8 \pm 1.59$ & $56.7 \pm 1.27$ & $57.0 \pm 0.93$ & $56.5 \pm 1.71$ & $56.4 \pm 1.58$ & $>0.50$ \\
\hline Protein & $11.3 \pm 0.46$ & $11.1 \pm 0.21$ & $10.9 \pm 0.21$ & $10.7 \pm 0.30$ & $10.5 \pm 0.26$ & $10.2 \pm 0.23$ & $>0.25$ \\
\hline Fat & $27.7 \pm 0.80$ & $27.7 \pm 0.71$ & $27.8 \pm 0.56$ & $27.2 \pm 0.98$ & $28.0 \pm 0.78$ & $28.0 \pm 0.73$ & $>0.50$ \\
\hline Ash & $0.92 \pm 0.02^{\mathrm{f}}$ & $1.42 \pm 0.04 \mathrm{e}^{\mathrm{e}}$ & $1.92 \pm 0.04^{\mathrm{d}}$ & $2.36 \pm 0.07^{c}$ & $2.92 \pm 0.08^{b}$ & $3.42 \pm 0.08^{a}$ & $<0.05$ \\
\hline Carbohydrates & $3.25 \pm 0.07^{\mathrm{a}}$ & $2.98 \pm 0.07^{\mathrm{a}}$ & $2.72 \pm 0.05^{b}$ & $2.68 \pm 0.07^{b}$ & $2.19 \pm 0.06^{c}$ & $1.92 \pm 0.05^{\mathrm{c}}$ & $<0.05$ \\
\hline Caloric value & 307 & 306 & 305 & 299 & 302 & 301 & \\
\hline
\end{tabular}

${ }^{\mathrm{a}-\mathrm{f}}$ means within the same row with different uppercase letters differing significantly among different samples of liver pâtés $(p<0.05)$;

${ }^{1}$ caloric value results are expressed as $\mathrm{kcal} / 100 \mathrm{~g}$, while the chemical composition data were expressed as $\mathrm{g} / 100 \mathrm{~g}$.

Similar results were obtained in previous studies, in which beef meat was partially (from $10 \%$ to $40 \%$ ) replaced by meat-bone paste in meat batters [15]. In this case, the authors observed that moisture and protein contents were not affected by the reformulation. However, according to our results, these authors also observed a progressive (not significant) decrease in protein content when increasing the meat-bone paste proportion. Due to meat-bone paste presenting a high content of ash, in the previous study, the authors also reported a dramatic increase in the ash content of meat batter when meat-bone paste was used as a meat replacement.

The calculated caloric value of liver pâtés with meat-bone paste varies from $299 \mathrm{kcal} / 100 \mathrm{~g}$ (MBP-15) to $306 \mathrm{kcal} / 100 \mathrm{~g}$ (MBP-5) and is not so different. However, the caloric value of the control pâté was slightly higher $307 \mathrm{kcal} / 100 \mathrm{~g}$. It is important to highlight that the differences between caloric values were not significant, and these values were similar among all treatments. This fact is related to the very similar caloric value of both beef liver and meat-bone paste (106 vs. $110 \mathrm{kcal} / 100 \mathrm{~g}$ in meat-bone paste and liver, respectively). In contrast to our finding, in another study, the authors reported a significant reduction of energy value when the meat-bone paste replaced beef meat in meat batters [15]. In this case, this significant reduction was directly related to the reduction of fat content in the reformulated samples, while in our study, as aforementioned, the fat content was constant in all samples, which explains the different behaviors in these studies.

The mineral profile of liver patés with meat-bone paste is shown in Table 5. As expected, the replacement of liver with meat-bone paste has significantly increased calcium, magnesium, phosphorous, and sodium content. Additionally, the iron content was significantly higher in MBP-20 and MBP-25 samples in comparison with the other batches. These results are directly related to the mineral composition of meat-bone paste, which, in accordance with previously published articles, presented very high amounts of these minerals. Therefore, as mentioned above, our findings reflect the change in both ash content and mineral composition with the reformulation. 
Table 5. Mineral composition (expressed as mg/100 g) of liver pâtés with meat-bone paste.

\begin{tabular}{|c|c|c|c|c|c|c|c|}
\hline \multirow{2}{*}{ Mineral } & \multirow{2}{*}{ Control } & \multicolumn{5}{|c|}{ Pâté Reformulated with Meat-Bone Paste } & \multirow{2}{*}{$p$ Value } \\
\hline & & MBP-5 & MBP-10 & MBP-15 & MBP-20 & MBP-25 & \\
\hline Calcium & $11.36 \pm 0.19^{f}$ & $165 \pm 4.21^{\mathrm{e}}$ & $319 \pm 7.81^{d}$ & $500 \pm 18.7^{c}$ & $626 \pm 10.9^{b}$ & $780 \pm 14.1^{\mathrm{a}}$ & $<0.001$ \\
\hline Potassium & $211 \pm 7.30^{\mathrm{a}}$ & $201 \pm 4.82^{\mathrm{a}}$ & $191 \pm 1.81^{b}$ & $181 \pm 5.91^{\mathrm{b}}$ & $171 \pm 6.04^{b, c}$ & $161 \pm 4.65^{\mathrm{c}}$ & $<0.01$ \\
\hline Magnesium & $12.6 \pm 0.27^{\mathrm{e}}$ & $17.7 \pm 0.39^{\mathrm{d}}$ & $22.7 \pm 0.64^{\mathrm{d}}$ & $25.0 \pm 0.76^{\mathrm{c}}$ & $32.7 \pm 0.73^{b}$ & $37.7 \pm 0.74^{\mathrm{a}}$ & $<0.001$ \\
\hline Sodium & $61.5 \pm 2.08^{\mathrm{f}}$ & $77.4 \pm 1.52 \mathrm{e}$ & $93.2 \pm 1.76^{\mathrm{d}}$ & $109 \pm 3.17^{c}$ & $125 \pm 2.50^{b}$ & $141 \pm 4.39^{\mathrm{a}}$ & $<0.001$ \\
\hline Phosphorous & $275 \pm 7.37^{\mathrm{f}}$ & $382 \pm 12.6^{\mathrm{e}}$ & $489 \pm 8.56^{d}$ & $596 \pm 10.8^{c}$ & $703 \pm 11.7^{b}$ & $810 \pm 18.4^{\mathrm{a}}$ & $<0.001$ \\
\hline Copper & $6.99 \pm 0.21^{\mathrm{a}}$ & $6.42 \pm 0.15^{\mathrm{a}}$ & $5.86 \pm 0.19^{b}$ & $5.29 \pm 0.16^{b}$ & $4.72 \pm 0.11^{\mathrm{c}}$ & $4.16 \pm 0.13^{c}$ & $<0.01$ \\
\hline Iron & $4.19 \pm 0.11^{b}$ & $4.20 \pm 0.10^{\mathrm{b}}$ & $4.32 \pm 0.12^{b}$ & $4.59 \pm 0.09^{b}$ & $4.64 \pm 0.16^{\mathrm{a}}$ & $4.86 \pm 0.12^{\mathrm{a}}$ & $<0.01$ \\
\hline Manganese & $0.20 \pm 0.01^{\mathrm{a}}$ & $0.19 \pm 0.01^{\mathrm{a}}$ & $0.17 \pm 0.01^{\mathrm{a}}$ & $0.16 \pm 0.01^{b}$ & $0.15 \pm 0.01^{b}$ & $0.14 \pm 0.01^{\mathrm{b}}$ & $<0.01$ \\
\hline Zinc & $3.09 \pm 0.08^{a}$ & $2.95 \pm 0.08^{a}$ & $2.82 \pm 0.09^{a}$ & $2.68 \pm 0.05^{b}$ & $2.54 \pm 0.07^{b}$ & $2.40 \pm 0.06^{b}$ & $<0.01$ \\
\hline
\end{tabular}

${ }^{\mathrm{a}-\mathrm{f}}$ means within the same row with different uppercase letters differing significantly among different samples of liver pâtés $(p<0.05)$.

On the contrary, the low content of potassium, copper, manganese, and zinc in meatbone paste determines that the content of these minerals decrease as the meat-bone paste replaced beef liver in the formulation of the reformulated pâtés.

As discussed, mineral profile analysis showed that samples MBP-20 and MBP-25 had the highest concentrations of calcium, phosphorous, and sodium compared to other samples. Thus, consumption of $100 \mathrm{~g}$ of liver pâté with 20 and $25 \%$ of meat-bone paste provides more than $50 \%$ of the recommended dietary allowance (RDA) of calcium and phosphorous to the human body (Table 6). However, excessive amounts of these elements can lead to serious diseases [38]. The amount of calcium increased from $11.4 \mathrm{mg} / 100 \mathrm{~g}$ in the control sample to $780 \mathrm{mg} / 100 \mathrm{~g}$ in MBP-25 (Table 5). Calcium is the main component of bone tissue and dentin and is vital for the healthy performance of nervous and cardiovascular systems and for the metabolism to help regulate the acid-base balance [39]. Calcium deficiency in the human body causes diseases such as osteoporosis, chronic illness of skeleton, and bone tissue. Moreover, hypertension symptoms are also related to calcium deficiency.

Table 6. Recommended daily allowance of minerals, $\mathrm{mg} /$ day.

\begin{tabular}{cccc}
\hline Mineral & Recommended $^{\mathbf{1}}$ & Maximum $^{\mathbf{2}}$ & Recommended for Children $^{\mathbf{3}}$ \\
\hline Calcium & $800-1200$ & 2500 & $400-1200$ \\
Magnesium & $300-400$ & - & $55-400$ \\
Potassium & $1500-2500$ & - & $400-2500$ \\
Sodium & $3000-5000$ & - & $200-1300$ \\
Phosphorous & $550-1400$ & - & $300-1200$ \\
Iron & $8-10$ (for men) & - & $4-18$ \\
& $15-20$ (for women) & & $3-12$ \\
Zinc & $11-15$ (for men) & 25 & $0.5-1.0$ \\
Copper & $10-12$ (for women) & 5 & 2 \\
Manganese & $0.9-2.3$ & 5 &
\end{tabular}

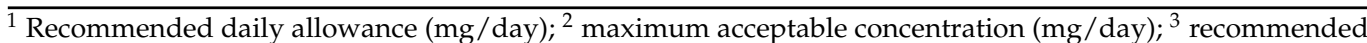
daily allowance for children ( $\mathrm{mg} /$ day).

The magnesium level increased three times from $12.6 \mathrm{mg} / 100 \mathrm{~g}$ in the control sample to $37.7 \mathrm{mg} / 100 \mathrm{~g}$ in liver pâté with $25 \% \mathrm{MBP}$. Magnesium is another essential element in the human body. Magnesium ions participate in more than 350 different biochemical processes, including the function of adenosine triphosphate, protein, carbohydrate, and lipid metabolisms and stabilizing enzymes [40]. Magnesium deficiency can result in the activation of inflammatory conditions and lead to oxidative damage of tissues, increased risk of hypertension, and heart diseases [41]. However, magnesium abundance impairs calcium bioavailability. 
The sodium content in the reformulated liver pâtés was found to be significantly higher than that of the control sample. Sodium plays a key role in water and electrolyte balance in the human body. However, excess sodium intake was related to multiple illnesses [42-44], such as slowing down body growth, raising blood pressure, and leading to heart and kidney dysfunctions.

Phosphorus compounds are presented in every cell of the human body and participate in the functioning of live activities. Therefore, the liver pâté reformulation produces an enrichment in this mineral. It provides energy for muscle actions, nervous impulses, and organic matter biosynthesis. Phosphorus plays an important role in calcium metabolism, brain functioning, muscle, and bone strength and is a part of DNA, RNA, and several ferments [45]. However, an excess amount of phosphorous can cause calcium loss and the deposit of mineral salts in muscles [46].

Iron is an integral component of the blood-forming process. It helps to produce red and white blood cells. Anemia is the most common disease of iron deficiency [47]. Excess iron has a bad effect on liver function [48].

However, among the minerals that reduce their content with the reformulation $(\mathrm{K}, \mathrm{Cu}$, $\mathrm{Mn}$, and $\mathrm{Zn}$ ), the highest reduction (up to $40 \%$ ) was observed for copper, while manganese, potassium, and zinc levels were reduced by $30 \%, 23 \%$, and 22\%, respectively. Potassium level was lower when increasing meat-bone paste in liver pâtés. Potassium functions as an intracellular ion, regulating the water, acid, and electrolytic balance and helps to lower blood pressure. Its deficiency has been linked to serious illnesses, such as cardiac failure, depressive syndrome, nightmares, kidney failure, etc. [49]. However, an excess level of potassium in the human body can lead to heart dysfunction, weakness, or adynamia [50].

Copper participates in iron metabolism and cell respiration and stimulates protein and carbohydrate digestibility. Copper is part of many vitamins, enzymes, and hormones [51].

Manganese is essential in forming bone and connective tissue. It is a part of many enzymes that participate in amino acid, carbohydrate, and catecholamine metabolism, stimulating cholesterol biosynthesis [52]. Lack of manganese in the human body causes different pathologic processes: a decrease of antibody response rate; neuropsychic disease; diabetes; brittleness of the bones; etc. [53].

Zinc is a vital microelement for the normal functioning of the human body. More than 300 enzymes contain zinc. This element participates in the synthesis and degradation of proteins, carbohydrates, fats, and nucleic acids [54]. Zinc deficiency could cause anemia, secondary immunodeficiency, and liver cirrhosis [55]. An excessive amount of zinc in the human body predisposes one to acute intoxication.

On the other hand, similar studies reported the calcium fortification of meat products. The mineral source supplements used are different types of bones (animal, poultry, fish) and mineral supplements. For example, Chinese scientists from Chengdu University and Sichuan Tianxian Food Co., Ltd. (Yan'an, China), patented a method of meat food products enriched with minerals, in particular calcium and phosphorous [56]. The source of mineral elements was the bones of animals, fish, and poultry, fish and poultry bones being treated with alkaline and acid solutions and heated. After the bones were finely crushed, an enzymatic treatment was performed to obtain a paste-like mass. This paste-like mass was used in formulations of meat products which allows for enriching with biologically active calcium and phosphorus [56].

Boyle et al. [57] developed low-fat sausages enriched with calcium carbonate and calcium citrate malate complex. In this case, the content of calcium in low-fat sausages enriched with calcium carbonate was approximately $550 \mathrm{mg} / 100 \mathrm{~g}$, and calcium citrate malate complex was $510 \mathrm{mg} / 100 \mathrm{~g}$. The current data obtained in our research for liver pâté with $15 \%$ of meat-bone paste were in agreement with the previous data [57].

Cáceres et al. [58] used calcium lactate, calcium gluconate, and calcium citrate in the formulation of cooked sausages. The concentration of calcium in sausages was up to $350 \mathrm{mg} / 100 \mathrm{~g}$. Fishbone powder processing technology was also reported [59]. Ustinova et al. [60] patented the production method of emulsified meat products enriched with 
minerals. The increase in calcium content $(227 \mathrm{mg} / 100 \mathrm{~g})$ was attributed to the addition of bone powder into the formulation of the meat products. Daengprok et al. [61] used eggshell calcium lactate powder in a recipe of Thai-style fermented pork sausage and observed that calcium supplementation should be limited to $150 \mathrm{mg} / 100 \mathrm{~g}$ (equivalent to $18.8 \%$ of the RDA for adults) [61]. Another study developed low-fat chicken patties fortified with 1.75\% of calcium lactate and determined $213 \mathrm{mg} / 100 \mathrm{~g}$ of calcium concentration, achieving $20 \%$ of RDA of calcium.

Therefore, according to our results of mineral composition, the optimal level of meatbone paste addition to liver paté formulation is $15 \%$. This amount provides the most balanced ratio of calcium to phosphorous (1:1.2) and the beneficial effect of better assimilation of calcium in the human body [62].

\subsection{Amino Acid Composition}

Adding meat-bone paste had a dramatic effect on the amino acid composition of liver pâté (Table 7).

Table 7. Amino acid composition (expressed as $\mathrm{mg} / 100 \mathrm{~g}$ ) of liver pâté.

\begin{tabular}{|c|c|c|c|c|c|c|c|}
\hline \multirow{2}{*}{ Amino Acid } & \multirow{2}{*}{ Control } & \multicolumn{5}{|c|}{ Pâté Reformulated with Meat-Bone Paste } & \multirow{2}{*}{$p$ Value } \\
\hline & & MBP-5 & MBP-10 & MBP-15 & MBP-20 & MBP-25 & \\
\hline Non-essential & $6080 \pm 109$ & $4995 \pm 89.9$ & $5083 \pm 91.5$ & $4586 \pm 82.5$ & $4088 \pm 73.6$ & $3590 \pm 64.4$ & \\
\hline Alanine & $718 \pm 7.71^{\mathrm{a}}$ & $583 \pm 8.72^{b}$ & $602 \pm 10.1^{b}$ & $544 \pm 6.41^{\mathrm{b}}$ & $485 \pm 5.15^{c}$ & $427 \pm 5.29^{c}$ & $<0.001$ \\
\hline Aspartic acid & $1177 \pm 24.9^{\mathrm{a}}$ & $967 \pm 18.2^{b}$ & $984 \pm 11.8^{b}$ & $888 \pm 14.6^{c}$ & $792 \pm 10.5^{d}$ & $695 \pm 8.24^{\mathrm{e}}$ & $<0.001$ \\
\hline Glycine & $702 \pm 9.12^{\mathrm{a}}$ & $583 \pm 7.38^{b}$ & $586 \pm 7.65^{b}$ & $528 \pm 6.73^{b}$ & $469 \pm 5.46^{\mathrm{c}}$ & $411 \pm 4.70^{\mathrm{d}}$ & $<0.001$ \\
\hline Glutamic acid & $1585 \pm 19.6^{\mathrm{a}}$ & $1312 \pm 16.8^{b}$ & $1324 \pm 19.3^{b}$ & $1193 \pm 12.6^{c}$ & $1063 \pm 12.3^{c}$ & $932 \pm 14.7^{\mathrm{d}}$ & $<0.001$ \\
\hline Proline & $603 \pm 11.2^{\mathrm{a}}$ & $481 \pm 7.30^{b}$ & $506 \pm 7.15^{b}$ & $458 \pm 6.51^{b}$ & $410 \pm 4.36^{c}$ & $362 \pm 4.62^{d}$ & $<0.001$ \\
\hline Serine & 555. $\pm 10.5^{\mathrm{a}}$ & $454 \pm 6.55^{b}$ & $465 \pm 9.40^{b}$ & $419 \pm 8.36^{b}$ & $374 \pm 5.66^{c}$ & $329 \pm 6.72^{d}$ & $<0.001$ \\
\hline Tyrosine & $483 \pm 9.20^{\mathrm{a}}$ & $405 \pm 5.88^{b}$ & $402 \pm 5.63^{b}$ & $362 \pm 3.92^{c}$ & $322 \pm 4.10^{\mathrm{c}}$ & $281 \pm 4.38^{d}$ & $<0.001$ \\
\hline Cystine & $232 \pm 3.50^{\mathrm{a}}$ & $188 \pm 3.37^{b}$ & $194 \pm 2.57^{b}$ & $175 \pm 2.43^{b}$ & $157 \pm 2.49^{\mathrm{c}}$ & $138 \pm 1.55^{\mathrm{d}}$ & $<0.001$ \\
\hline Oxyproline & $25.3 \pm 0.37^{\mathrm{a}}$ & $23.0 \pm 0.38^{b}$ & $20.7 \pm 0.32^{b}$ & $18.4 \pm 0.28^{c}$ & $16.1 \pm 0.30^{d}$ & $13.8 \pm 0.27^{\mathrm{e}}$ & $<0.02$ \\
\hline Essential & $6280 \pm 113$ & $5610 \pm 100$ & $6070 \pm 109$ & $5965 \pm 107$ & $5860 \pm 105$ & $5756 \pm 103$ & \\
\hline Arginine & $741 \pm 14.9^{\mathrm{a}}$ & $622 \pm 6.43^{b}$ & $617 \pm 8.08^{b}$ & $555 \pm 8.42^{c}$ & $493 \pm 9.02^{\mathrm{d}}$ & $431 \pm 6.22^{\mathrm{e}}$ & $<0.001$ \\
\hline Histidine & $409 \pm 5.03^{b}$ & $356 \pm 4.26^{b}$ & $427 \pm 6.67^{b}$ & $436 \pm 6.87^{b}$ & $445 \pm 7.82^{\mathrm{a}}$ & $454 \pm 6.57^{\mathrm{a}}$ & $<0.02$ \\
\hline Valine & $754 \pm 13.1$ & $686 \pm 7.15$ & $738 \pm 112$ & $730 \pm 9.76$ & $722 \pm 7.69$ & $714 \pm 5.38$ & $<0.02$ \\
\hline Isoleucine & $588 \pm 11.5$ & $535 \pm 8.08$ & $592 \pm 10.9$ & $593 \pm 7.15$ & $595 \pm 7.02$ & $597 \pm 6.89$ & $>0.50$ \\
\hline Leucine & $1149 \pm 22.8$ & $1042 \pm 18.1$ & $1128 \pm 18.9$ & $1118 \pm 15.9$ & $1107 \pm 16.1$ & $1097 \pm 13.5$ & $>0.25$ \\
\hline Lysine & $969 \pm 9.04$ & $898 \pm 16.4$ & $994 \pm 12.8$ & $1006 \pm 13.2$ & $1018 \pm 16.7$ & $1030 \pm 13.4$ & $>0.25$ \\
\hline Methionine & $322 \pm 5.05^{\mathrm{a}}$ & $297 \pm 2.65^{b}$ & $318 \pm 4.71^{\mathrm{a}}$ & $316 \pm 4.58^{\mathrm{a}}$ & $313 \pm 5.15^{\mathrm{a}}$ & $311 \pm 4.89^{\mathrm{a}}$ & $<0.01$ \\
\hline Threonine & $533 \pm 6.07^{\mathrm{a}}$ & $460 \pm 5.44^{b}$ & $496 \pm 8.46^{\mathrm{a}}$ & $478 \pm 6.20^{b}$ & $459 \pm 8.25^{b}$ & $441 \pm 6.89^{b}$ & $<0.02$ \\
\hline Tryptophan & $161 \pm 2.25^{a}$ & $132 \pm 1.68^{b}$ & $135 \pm 2.32^{b}$ & $122 \pm 1.77^{\mathrm{b}}$ & $108 \pm 1.70^{b}$ & $95.2 \pm 1.23^{c}$ & $<0.001$ \\
\hline Phenylalanine & $654 \pm 10.7^{\mathrm{a}}$ & $583 \pm 9.12^{b}$ & $627 \pm 7.04^{\mathrm{a}}$ & $613 \pm 13.0^{\mathrm{a}}$ & $599 \pm 8.32^{\mathrm{a}}$ & $586 \pm 8.76^{b}$ & $<0.05$ \\
\hline Total Amino Acids & $12360 \pm 223$ & $10605 \pm 191$ & $11154 \pm 201$ & $10551 \pm 190$ & $9948 \pm 179$ & $9345 \pm 168$ & \\
\hline
\end{tabular}

Replacing 20 or $25 \%$ of the liver with the same amount of meat-bone paste significantly increased the content of histidine (from $409 \mathrm{mg} / 100 \mathrm{~g}$ in the control sample up to $454 \mathrm{mg} / 100 \mathrm{~g}$ in the MBP-25 sample). The same trend was obtained for lysine and isoleucine, but in these cases, the differences were not significant.

The content of the other amino acids decreased when increasing amounts of meat-bone paste. For the most part, all non-essential amino acids were reduced on average by $40 \%$, except for oxyproline (reduced by more than $45 \%$ ). Among the essential amino acids, the average reduction was $5 \%$, except for threonine $(17 \%)$ and tryptophane $(41 \%)$.

The reduction of total non-essential amino acids was $40.9 \%$ (6080 vs. $3590 \mathrm{mg} / 100 \mathrm{~g}$ in control and MBP-25, respectively), while the total essential amino acids only decreased by $8.30 \%$ (6280 vs. $5756 \mathrm{mg} / 100 \mathrm{~g}$ in control and MBP-25, respectively). This aspect is very important from a nutritional point of view since essential amino acids participate 
in the synthesis of proteins and have a direct effect on weight gain. Moreover, each one performs its own specific functions. Lysine and tryptophan are required for growth; lysine with histidine participates in blood formation [63]. Methionine has a great effect on fat and phosphatide metabolism, which plays a role in nervous functions. Cystine has a strong antioxidant activity which increases with the presence of vitamin $C$ and selenium; goat milk has a high content of both [64]. Leucine, isoleucine, and valine are the basic amino acids for protein metabolism. These amino acids are the main source of energy for the muscles, reduce the rate of protein breakdown, and support muscle mass and protein synthesis during physical stress [65].

In observing the reduction in total amino acid content (from 12,360 mg/100 $\mathrm{g}$ in control to $9345 \mathrm{mg} / 100 \mathrm{~g}$ in MBP-25), as well as the reduction in protein content discussed above, a decrease in amino acid content was expected. In fact, our results agree with those reported in a previous study, in which the authors found a significant decrease of total, essential, and non-essential amino acids in meat batters reformulated with $10-40 \%$ of meat bone paste [15]. However, in the present study, the particular amino acid composition of meatbone paste [16], rich in valine ( $8.10 \%$ of protein), isoleucine (7.40 \% of protein), leucine (12.5\% of protein), and lysine (13.6\% of protein), demonstrates that the reformulation did not influence the content of these important essential amino acids. In comparison, according to a recent paper [37], the content of these amino acids in beef liver (3.51, 5.67, 7.99 , and $7.37 \%$ of protein for valine, isoleucine, leucine, and lysine, respectively) is lower than the values reported for meat-bone paste, which explains our findings in this research.

\section{Conclusions}

The liver pâté developed by using meat-bone paste yielded a high-quality food product enriched with minerals, such as calcium, magnesium, and iron, satisfying up to $50 \%$ of the normal RDA. This innovative type of liver pâté expands the range of canned foods on the market and increases the cost efficiency by using lower-cost ingredients obtained from using meat processing industry by-products. Moreover, the consumption of liver pâté with meat and bone paste might be beneficial for the issue of mineral deficiency in the human body and osteoporosis disease prevention. This study showed that partial replacement of liver with meat-bone paste significantly increases the calcium, magnesium, sodium, and phosphorous content in liver pâtés. According to the mineral balance, the optimal amount of meat-bone paste in pâte formulation should be up to $15 \%$. In this case, the consumption of $100 \mathrm{~g}$ of pâte provides $50 \%$ of the RDA of calcium and phosphorous to the human body.

In general, the changes in chemical compositions did not affect the main macronutrients (fat and protein) of the product, while the amino acid composition changed with the reformulation. In this regard, a dramatic decrease of the non-essential amino acids was found, but the change in essential amino acids content was limited, thus confirming that the use of meat-bone paste as an ingredient is good for producing healthy pâtés. Therefore, partial replacement of beef liver meat-bone paste reduces production costs and offers the possibility of reusing nutritive by-products of the meat industry, while enriching meat batters with minerals and essential amino acids.

Author Contributions: Conceptualization, Z.Y.; methodology, A.S. and B.K.; software, A.B.; validation, A.K., formal analysis, N.C.; investigation, Z.Y. and A.S.; resources, M.A.S.; data curation, N.C.; writing—original draft preparation, Z.Y. and R.D.; writing—review and editing, N.C., R.D. and J.M.L.; visualization, M.A.S.; supervision, A.K.; project administration, Z.Y.; funding acquisition, A.S. All authors have read and agreed to the published version of the manuscript.

Funding: This research was funded by Ministry of Agriculture of Kazakhstan, grant number IRN BR10764970. The APC was funded by Ministry of Agriculture of Kazakhstan.

Data Availability Statement: The data presented in this study are available on request from the corresponding author. 
Acknowledgments: Thanks to GAIN (Axencia Galega de Innovación) for supporting this study (grant number IN607A2019/01). Rubén Domínguez and José M. Lorenzo are members of the HealthyMeat network, funded by CYTED (ref. 119RT0568).

Conflicts of Interest: The authors declare no conflict of interest. The funders had no role in the design of the study; in the collection, analyses, or interpretation of data; in the writing of the manuscript; or in the decision to publish the results.

\section{References}

1. Hamzeh, A.; Azizieh, A.; Yazagy, S. Effect of the Fat Percentage and Liver Type in the Stability and pH Value of Locally Prepared Liver Pate. Int. Food Res. J. 2016, 23, 1131-1135.

2. Xiong, G.; Wang, P.; Zheng, H.; Xu, X.; Zhu, Y.; Zhou, G. Effects of Plant Oil Combinations Substituting Pork Back-Fat Combined with Pre-Emulsification on Physicochemical, Textural, Microstructural and Sensory Properties of Spreadable Chicken Liver PÂTÉ. J. Food Qual. 2016, 39, 331-341. [CrossRef]

3. Munekata, P.E.S.; Domínguez, R.; Campagnol, P.C.B.; Franco, D.; Trindade, M.A.; Lorenzo, J.M. Effect of natural antioxidants on physicochemical properties and lipid stability of pork liver pâté manufactured with healthy oils during refrigerated storage. J. Food Sci. Technol. 2017, 54, 4324-4334. [CrossRef] [PubMed]

4. Domínguez, R.; Agregán, R.; Gonçalves, A.; Lorenzo, J.M. Effect of fat replacement by olive oil on the physico-chemical properties, fatty acids, cholesterol and tocopherol content of pâté. Grasas Aceites 2016, 67, e133.

5. Tiensa, B.E.; Barbut, S.; Marangoni, A.G. Influence of fat structure on the mechanical properties of commercial pate products. Food Res. Int. 2017, 100, 558-565. [CrossRef] [PubMed]

6. Vargas-Ramella, M.; Pateiro, M.; Barba, F.J.; Franco, D.; Campagnol, P.C.B.; Munekata, P.E.S.; Tomasevic, I.; Domínguez, R.; Lorenzo, J.M. Microencapsulation of healthier oils to enhance the physicochemical and nutritional properties of deer pâté. $L W T$ 2020, 125, 109223. [CrossRef]

7. Madruga, M.S.; Stephen Elmore, J.; Dodson, A.T.; Mottram, D.S. Volatile flavour profile of goat meat extracted by three widely used techniques. Food Chem. 2009, 115, 1081-1087. [CrossRef]

8. Domínguez, R.; Purriños, L.; Pérez-Santaescolástica, C.; Pateiro, M.; Barba, F.J.; Tomasevic, I.; Campagnol, P.C.B.; Lorenzo, J.M. Characterization of volatile compounds of dry-cured meat products using HS-SPME-GC/MS technique. Food Anal. Methods 2019, 12, 1263-1284. [CrossRef]

9. Domínguez, R.; Pateiro, M.; Gagaoua, M.; Barba, F.J.; Zhang, W.; Lorenzo, J.M. A comprehensive review on lipid oxidation in meat and meat products. Antioxidants 2019, 8, 429. [CrossRef]

10. Lorido, L.; Estévez, M.; Ventanas, S. A novel approach to assess temporal sensory perception of muscle foods: Application of a time-intensity technique to diverse Iberian meat products. Meat Sci. 2014, 96, 385-393. [CrossRef]

11. Yude, L. Comprehensive Utilization of Animal Bones. Food Sci. 2000, 2, 1-10.

12. Peshuk, L.; Budnyk, N.; Halenko, O. Gerodietic Meat Products Technology Enriched with Calcium and Phosphorus. Food Environ. Saf. 2011, 10, 18-23.

13. Kakimov, A.; Kabdylzhar, B.; Yessimbekov, Z.; Suychinov, A.; Baikadamova, A. Identifying patterns in the effect exerted by a cooling process and the fine grinding modes on the qualitative indicators of a meat and bone paste. East.-Eur. J. Enterp. Technol. 2020, 2, 6-12. [CrossRef]

14. Regulation (EC) No 1069/2009 European Parliament and of the Council of 21 October 2009 laying down health rules as regards animal by-products and derived products not intended for human consumption and repealing Regulation (EC) No 1774/2002 (Animal by-products Regulation). Off. J. Eur. Union 2009, L300, 1-33.

15. Kakimov, A.; Suychinov, A.; Mayorov, A.; Yessimbekov, Z.; Okuskhanova, E.; Kuderinova, N.; Bakiyeva, A. Meat-bone paste as an ingredient for meat batter, effect on physicochemical properties and amino acid composition. Pak. J. Nutr. 2017, 16, 797-804. [CrossRef]

16. Kakimov, A.; Kabdylzhar, B.; Suychinov, A.; Yessimbekov, Z.; Baikadamova, A.; Zolotov, A.; Zharykbasova, K. The chemical profile and the effect of temperature and storage time on the change of yield stress and $\mathrm{pH}$ of meat-bone paste. Eur. Asian J. Biosci. 2019, 13, 2093-2097.

17. Domínguez, R.; Pateiro, M.; Munekata, P.E.S.; Campagnol, P.C.B.; Lorenzo, J.M.; Sichetti Munekata, P.E.; Bastianello Campagnol, P.C.; Lorenzo, J.M. Influence of partial pork backfat replacement by fish oil on nutritional and technological properties of liver pâté. Eur. J. Lipid Sci. Technol. 2017, 119, 1600178. [CrossRef]

18. Okuskhanova, E.; Assenova, B.; Rebezov, M.; Yessimbekov, Z.; Kulushtayeva, B.; Zinina, O.; Stuart, M. Mineral composition of deer meat pate. Pak. J. Nutr. 2016, 15, 217-222. [CrossRef]

19. Bayer, N.A.; Nekludov, A.D.; Dubina, V.I.; Telyashevskaya, L.Y.; Aleshin, A.A.; Lunev, G.G.; Timoshkina, E.A.; Lamm, E.L. Method of Production of Protein Hydrolyzate from Meat and Meat-Bone Raw Material 2000. Available online: https:/ / patents. google.com/patent/RU2160538C1/ru (accessed on 28 August 2021).

20. Kutsakova, V.E.; Frolov, S.V.; Udachin, S.P.; Goryainov, S.N.; Marchenko, V.I. Method of Hydrolyzates Production from the Bone Wastes of Poultry and Fish. 2006. Available online: https://patents.google.com/patent/RU2272418C1/ru?oq=2272418 (accessed on 28 August 2021).

21. Soshieeda, K.K. Method for Producing Bone-Mixed Meat Paste. Japan Patent No. 2012210197, 1 November 2012. 
22. Kinichi, E.; Tatsu, M. Production of Fish Bone Paste and Utilization of Fish Bone Paste. Japan Patent No. 04-190768, 9 July 1992.

23. Amirkhanov, K.; Igenbayev, A.; Nurgazezova, A.; Okuskhanova, E.; Kassymov, S.; Muslimova, N.; Yessimbekov, Z. Comparative Analysis of Red and White Turkey Meat Quality. Pak. J. Nutr. 2017, 16, 412-416. [CrossRef]

24. Kyoichi, I. Japan Calcium-Rich Health Food. Japan Patent No. 03-078463, 13 October 1992.

25. Shinjuro, N. Meat-like Composition and Its Preparation. Japan Patent No. 58-205472, 30 November 1983.

26. GOST 12319-77. The Standard Applies to Canned Meat "Liver Pate", Packed in Cans, Hermetically Sealed and Sterilized. 2012. Available online: https:/ / docs.cntd.ru/document/1200021499 (accessed on 28 August 2021).

27. Toldrá, F.; Group, F. Handbook of Analysis of Edible Animal By-Products, 1st ed.; Toldrá, F., Group, F., Eds.; CRC Press: Boca Raton, FL, USA, 2011; ISBN 9781439803608.

28. GOST 9793-74. Method of Moisture Determination. 2010. Available online: https://docs.cntd.ru/document/901712025 (accessed on 28 August 2021).

29. GOST R 51479-99. Method for Determination of Moisture Content. 2010. Available online: https://docs.cntd.ru/document/1200 028186 (accessed on 28 August 2021).

30. GOST 23042-86. Method of Fat Determination. 2010. Available online: https://docs.cntd.ru/document/1200021649 (accessed on 28 August 2021).

31. GOST 25011-81. Method of Protein Determination. 2010. Available online: https://docs.cntd.ru/document/1200021660 (accessed on 28 August 2021).

32. Rudenko, A.O.; Kartsova, L.A. Determination of the most important amino acids in complex objects of biological origin by reversed-phase HPLC with obtaining phenylthiohydantoin amino acids. Sorption Chromatogr. Process. 2010, 10, $223-230$.

33. Rao, M.; Gault, N.; Kennedy, S. Changes in the Ultrastructure of Beef Muscle as Influenced by Acidic Conditions Below the Ultimate pH. Food Struct. 1989, 8, 115-124.

34. Kakimov, A.; Yessimbekov, Z.; Kabulov, B.; Bepeyeva, A.; Kuderinova, N.; Ibragimov, N. Studying Chemical Composition and Yield Stress of Micronized Grinded Cattle Bone Paste. Res. J. Pharm. Biol. Chem. Sci. 2016, 7, 805-8012.

35. Kakimov, A.K.; Kabulov, B.B.; Yessimbekov, Z.S.; Kuderinova, N.A. Use of meat-bone paste as a protein source in meat product production. Theory Pract. Meat Process. 2016, 1, 42-50. [CrossRef]

36. Kakimov, A.; Yessimbekov, Z.; Suychinov, A.; Japanov, T.; Zolotov, A. Mineral and amino acid composition of meat-bone paste. Int. Sci. Pract. Conf. WORLD Sci. 2017, 5, 5-7.

37. Kakimov, A.; Suychinov, A.; Tsoy, A.; Mustambayev, N.; Ibragimov, N.; Kuderinova, N.; Mirasheva, G.; Yessimbekov, Z. Nutritive and biological value of liver and blood of various slaughtered animals. J. Pharm. Res. Int. 2018, 22, 1-5. [CrossRef]

38. Sitalakshmi, R.; Kumar, S.P. Trace Elements in Health and Disease: A Review. Res. J. Pharm. Biol. Chem. Sci. $2014,5,450-455$.

39. Beto, J.A. The Role of Calcium in Human Aging. Clin. Nutr. Res. 2015, 4, 8. [CrossRef]

40. Aikawa, J.K. Magnesium: It's Biologic Significance, 1st ed.; Aikawa, J.K., Ed.; CRC Press: Boca Raton, FL, USA, 1981; ISBN 9780367226374 .

41. Gröber, U.; Schmidt, J.; Kisters, K. Magnesium in Prevention and Therapy. Nutrients 2015, 7, 8199-8226. [CrossRef]

42. Domínguez, R.; Pateiro, M.; Pérez-Santaescolástica, C.; Munekata, P.E.S.; Lorenzo, J.M. Salt reduction strategies in meat products made from whole pieces. In Strategies for Obtaining Healthier Foods; Lorenzo, J.M., Carballo, F.J., Eds.; Nova Science Publishers: Hauppauge, NY, USA, 2017; pp. 267-289. ISBN 978-1-53612-159-9.

43. Pedro, D.; Saldaña, E.; Lorenzo, J.M.; Pateiro, M.; Dominguez, R.; Dos Santos, B.A.; Cichoski, A.J.; Campagnol, P.C.B. Low-sodium dry-cured rabbit leg: A novel meat product with healthier properties. Meat Sci. 2021, 173, 108372. [CrossRef]

44. Pateiro, M.; Munekata, P.E.S.; Cittadini, A.; Domínguez, R.; Lorenzo, J.M. Metallic-based salt substitutes to reduce sodium content in meat products. Curr. Opin. Food Sci. 2021, 38, 21-31. [CrossRef]

45. Rebrov, V.G.; Gromova, O.A. Vitamins, Macro-and Micronutrients, 1st ed.; Rebrov, V.G., Gromova, O.A., Eds.; GEOTAR-Media: Moscow, Rusia, 2008.

46. Raina, R.; Garg, G.; Sethi, S.K.; Schreiber, M.J.; Simon, J.F.; Thomas, G. Phosphorus Metabolism. J. Nephrol. Ther. 2012, 3, 1-7. [CrossRef]

47. Yeung, D.L. Iron and micronutrients: Complementary food fortification. Food Nutr. Bullet 1998, 19, 159-163. [CrossRef]

48. Troshina, E.A.; Platonova, N.M. Iodine metabolism and prevention of iodine deficiency diseases in children and teenagers. Issues Mod. Pediatr. 2008, 4, 71-72.

49. Naismith, D.; Braschi, A. The effect of low-dose potassium supplementation on blood pressure in apparently healthy volunteers Br. J. Nutr. 2003, 90, 53-60. [CrossRef] [PubMed]

50. Nieder, R.; Benbi, D.K.; Reichl, F.X. Macro- and Secondary Elements and Their Role in Human Health. In Soil Components and Human Health; Nieder, R., Benbi, D.K., Reichl, F.X., Eds.; Springer: Dordrecht, Switzerland, 2018; pp. 257-315.

51. McCormick, F.; Nwachukwu, B.; Provencher, M. Stress fractures in runners. Clin. Sports Med. 2012, 31, 291-306. [CrossRef] [PubMed]

52. Nekrasov, V.I.; Skalny, A.V.; Oak, R.M. Role of microelements in increasing the functional reserves of the human body. Bull. Russ. Mil. Med. Acad. 2006, 1, 111-113.

53. Mena, I. The role of manganese in human disease. Ann. Clin. Lab. Sci. 1974, 4, 487-491. [PubMed]

54. Podobed, V.M. Zinc Carnosine: A new formula for gastroprotection and zinc deficiency. Med. News $2015,2,17$.

55. Halliulina, S.V. Clinical significance of zinc deficiency in a child's body (literature review). Bull. Mod. Clin. Med. 2013, 6, 72-78. 
56. Wang, W.; Gou, T.; Liu, D. Method for Processing Meat Product Rich in Mineral Substances of Biological Active Calcium and the Like. 2012. Available online: https:/ / patents.google.com/patent/CN102669715B/en (accessed on 28 August 2021).

57. Boyle, E.A.E.; Addis, P.B.; Epley, R.J. Calcium Fortified, Reduced Fat Beef Emulsion Product. J. Food Sci. 1994, 59, 928-932. [CrossRef]

58. Cáceres, E.; García, M.L.; Selgas, M.D. Design of a new cooked meat sausage enriched with calcium. Meat Sci. 2006, 73, 368-377. [CrossRef] [PubMed]

59. Hemung, B.-O.; Yongsawatdigul, J.; Chin, K.B.; Limphirat, W.; Siritapetawee, J. Silver Carp Bone Powder as Natural Calcium for Fish Sausage. J. Aquat. Food Prod. Technol. 2018, 27, 305-315. [CrossRef]

60. Ustinova, A.V.; Timoshenko, N.V.; Lyubina, N.V.; Soldatova, N.E.; Verkhosova, A.V. Homogenized Meat Product for Child Nutrition. Russian Federation Patent 2160546, 20 December 2000, Bul. 6, 4p.

61. Daengprok, W.; Garnjanagoonchorn, W.; Mine, Y. Fermented pork sausage fortified with commercial or hen eggshell calcium lactate. Meat Sci. 2002, 62, 199-204. [CrossRef]

62. Mehta, N.; Sharma, B.D.; Kumar, R.R.; Kumar, P.; Malav, O.P.; Verma, A.K. Fortification of low-fat chicken meat patties with calcium, vitamin E and vitamin C. Nutr. Food Sci. 2015, 45, 688-702. [CrossRef]

63. Ha, E.; Zemel, M. Functional properties of whey, whey components, and essential amino acids: Mechanisms underlying health benefits for active people (review). J. Nutr. Biochem. 2003, 14, 251-258. [CrossRef]

64. Ahluwalia, V.K.; Kumar, L.S.; Kumar, S. Chemistry of Natural Product: Amino Acids, Peptides, Proteins, and Enzymes; Ahluwalia, V.K., Kumar, L.S., Kumar, S., Eds.; CRC Press: Boca Raton, FL, USA, 2006; ISBN 1420059173.

65. Rennie, M.; Tipton, K. Protein and amino acid metabolism during and after exercise and the effects of nutrition. Annu. Rev. Nutr. 2000, 20, 457-483. [CrossRef] 